\title{
Pelayanan Keagamaan di Kawasan Perbatasan Entikong dan Sekayam, Provinsi Kalimantan Barat
}

\author{
Fakhruddin \\ Puslitbang Bimas Agama dan Layanan Keagamaan \\ oedein@gmail.com \\ dan \\ M. Ishom \\ Dosen Fakultas Syariah IAIN Sultan Maulana Hasanuddin, Banten \\ Artikel diterima 18 Mei, diseleksi 7 Juli, dan disetujui 28 Juli 2017
}

\begin{abstract}
Entikong and Sekayam are two sub-districts in Sanggau directly adjacent to the territory of Malaysia. Both sub-districts have been designated as priority sites of border areas development. Religious services in the border areas are still far from expectations and do not reflect the principle of satisfactory service community as stipulated in Ministrial Decree PAN No. 63/ KEP/M.PAN/7/2003. It is caused by many factors. So, related to the functions of implementation of development in the religious field, the Ministry of Religious Affair has adopted program of ibadah (religious worship). General religious services are part of the public services, i.e all activities undertaken by public service providers as effort to meet the needs of service recipients, as well as in order to implement the statutory provisions. The main basis of religious services in Indonesia are the first principle of Pancasila and Article 27 of the 1945 Constitution. Religious services in Indonesia can be conducted by public service providers, both government and socio-civil elements. It is unique, because despite Indonesia is not a religious state, the great role of religion in the history of the state formation can not be denied. Therefore, Indonesia government does not let the religious affair to be in the private domain but it is involved in conducting religious services in accordance with statutory provisions. The scope of religious services conducted by state according to law include: Islamic marriage, zakat/ infaq/charity/endowments, pilgrimage, religious education, and so forth. Out of those aforementioned, religious services is submitted to the social and religious institutions.
\end{abstract}

Keywords: Religious Service, Border Area and The Office of Religious Affairs.

\begin{abstract}
Abstrak
Entikong dan Sekayam adalah dua kecamatan di Sanggau yang berbatasan langsung dengan wilayah Malaysia. Kedua kecamatan tersebut telah ditunjuk sebagai lokasi prioritas pengembangan wilayah perbatasan. Pelayanan keagamaan di daerah perbatasan masih jauh dari harapan dan tidak mencerminkan prinsip pelayanan masyarakat yang memuaskan sebagaimana ditetapkan dalam Keputusan Menteri PAN No. 63 / KEP / M.PAN / 7/2003. Hal ini disebabkan oleh banyak faktor. Jadi, terkait dengan fungsi pelaksanaan pembangunan di bidang agama, Kementerian Agama telah mengadopsi program ibadah. Pelayanan keagamaan merupakan bagian dari pelayanan publik, yaitu semua kegiatan yang dilakukan oleh penyedia layanan publik sebagai upaya untuk memenuhi kebutuhan penerima layanan, serta untuk melaksanakan ketentuan undangundang. Dasar utama ibadah di Indonesia adalah asas pertama Pancasila dan Pasal 27 UUD 1945. Pelayanan keagamaan di Indonesia dapat dilakukan oleh penyedia layanan publik, baik elemen pemerintah maupun sosio-kewarganegaraan. Ini unik, karena meski Indonesia bukan negara berdasarkan agama, namun peran agama dalam sejarah pembentukan negara tidak dapat dipungkiri. Oleh karena itu, pemerintah Indonesia tidak membiarkan urusan keagamaan berada di ranah privat namun terlibat dalam melakukan ibadah sesuai dengan ketentuan perundang-undangan. Ruang lingkup ibadah yang dilakukan oleh negara menurut hukum meliputi: pernikahan islami, zakat / infaq / amal / wakaf, ziarah, pendidikan agama, dan sebagainya. Dari hal tersebut, pelayanan keagamaan diserahkan ke lembaga sosial dan keagamaan.
\end{abstract}

Kata kunci: Dinas Agama, Perbatasan dan Kantor Urusan Agama. 


\section{Latar Belakang}

Pembangunan kawasan perbatasan merupakan salah satu komitmen dan kebijakan pembangunan yang telah digariskan dalam Rencana Pembangunan Jangka Panjang Nasional (RPJPN) 20042025 dan Rencana Pembangunan Jangka Menengah Nasional (RPJMN) 20042009. Dalam Rencana Pembangunan Jangka Panjang 2004-2025, salah satu arah kebijakan pembangunan dalam rangka mewujudkan pembangunan yang merata dan dapat dinikmati oleh seluruh komponen bangsa di berbagai wilayah Indonesia dilakukan melalui pengembangan kawasan perbatasan.

Pengembangan kawasan perbatasan dikemukakan pula secara lebih tegas di dalam rencana Pembangunan Jangka Menengah Nasional (RPJMN) 2004-2009 khususnya dalam agenda pengurangan ketimpangan antar wilayah. Salah satu sasaran pengurangan ketimpangan antar wilayah adalah terwujudnya percepatan pembangunan di wilayah-wilayah cepat tumbuh dan strategis, wilayah tertinggal, termasuk wilayah perbatasan dalam suatu "sistem wilayah pengembangan ekonomi@ yang terintegrasi dan sinergis". Untuk mencapai sasaran ini, kebijakan pembangunan jangka menengah diarahkan pada upaya untuk pengembangan kawasan perbatasan dengan mengubah arah kebijakan pembangunan yang selama ini cenderung berorientasi inward looking menjadi outward looking. Orientasi outward looking dimaknai kedalam upaya-upaya untuk memanfaatkan kawasan perbatasan sebagai pintu gerbang aktivitas ekonomi dan perdagangan dengannegara tetangga. Adapun pendekatan pembangunan yang dilakukan selain menggunakan pendekatan yang bersifat keamanan, juga diperlukan pendekatan kesejahteraan, termasuk pendekatan lingkungan.

Di dalam Rencana Pembangunan Jangka Menengah Nasional 2004-2009, telah ditetapkan Program Pengembangan Wilayah Perbatasan yang dilaksanakan untuk mencapai dua tujuan sekaligus, yaitu: (1) menjaga keutuhan wilayah NKRI melalui penetapan hak kedaulatan NKRI yang dijamin oleh hokum internasional; dan (2) meningkatkan kesejahteraan masyarakat setempat dengan menggali potensi ekonomi, sosial dan budaya, serta keuntungan lokasi geografis yang sangat strategis untuk berhubungan dengan negara tetangga. Dari tujuan dasar pembangunan wilayah perbatasan itu, orientasi pembangunan yang menonjol terkesan mengedepankan aspek fisik semata. Tetapi hakekatnya tidak demikian sebab kesejahteraan meniscayakan kebutuhan nilai-nilai spiritual seperti rasa cinta tanah air sebagai pondasi nasionalisme, dan nilai ketuhanan dan moralitas sebagai pilar pembangunan karakter manusia.

Apalagi masalah social keagamaan yang merebak dewasa ini di daerah perbatasan ialah; (a) eksploitasi anak di bawah umur. Laki-laki banyak putus sekolah karena memilih bekerja. Perempuannya tidak jauh berbeda, bahkan banyak yang terjerumus menjadi wanita penghibur; (b) maraknya perkawinan di bawah tangan dan prostitusi; (c) merebaknya peredaran narkoba hingga ke pelosok kampong; (d) pemahaman keagamaan masyarakat masih sangat kurang. Jika masalah itu tidak tertangani tentu akan ada kesenjangan antara pembangunan fisik dengan pembangunan karakter masyarakat perbatasan.Oleh sebab itu pembangunan sector agama hendaknya menjadi bagian prioritas pengembangan wilayah perbatasan. Kementerian Agama sebagai entitas tekniskeagamaan memiliki tanggung jawab di bidang pembangunan agama di daerah perbatasan terutama di Kabupaten Sanggau

$$
\begin{gathered}
\text { Untuk itu penting dilakukan } \\
\text { kajian tentang pelayanan yang }
\end{gathered}
$$


dilakukan Kementerian Agama untuk daerah-daerah perbatasan, selain dapat menjadi bahan evaluasi, diharapkan akan mampu mendorong masyarakat perbatasan memperoleh akses pelayanan keagamaan dengan baik untuk kemajuan pembangunan daerah perbatasan. Tujuan penelitian untuk : 1) Menemukan problem-problem faktual tentang pelayanan keagamaan, problem apa saja yang dialami terutama yang diberikan oleh Kementerian Agama di daerah perbatasan, dan bagaimana kebudayaan negara tetangga berpengaruh terhadap pelayanan yang ada di Indonesia; 2) untuk mengetahui kebijakan, program, dan pembangunan fisik apa saja yang dilakukan secara spesifik oleh Kementerian Agama bagi pengembangan daerah perbatasan; dan 3) Untuk melakukan identifikasi pelayanan keagamaan apa saja yang dilakukan serta pelayanan yang mungkin bisa dikembangkan oleh Kementerian Agama dalam rangka pembangunan daerah perbatasan.

\section{Metode Penelitian}

Kajian ini menggunakan pendekatan kualitatif. Sebagai alat utama dalam pengumpulan data dilakukan observasi, wawancara mendalam, dan FGD (Focus Group Discussion). Untuk wawancara, informan yang dilibatkan dalam penggalian data terdiri dari key informan seperti tokoh masyarakat, tokoh agama, pejabat struktural Kankemenag yang terdiri dari usur staf dan pejabat Kantor Kementerian Agama Kabupaten Sanggau Provinsi Kalimantan Barat. Sedangkan pengumpulan data yang dilakukan melalui diskusi terfokus (FGD) dilakukan di Kantor Kementerian Agama Kabupaten Sanggau Provinsi Kalimantan Barat yang pesertanya terdiri dari anggota masyarakat, tokoh agama dan tokoh masyarakat, yang dianggap mempunyai informasi yang dibutuhkan dalam penelitian ini. Peserta FGD dengan jumlah 14 orang. Dengan jumlah peserta yang terbatas tersebut diharapkan semuanya dapat berkontribusi mengemukakan pendapatnya. Sementara untuk data pendukung diperoleh dari melakukan review berbagai buku, hasil penelitian, dokumen dan laporan, baik dari institusi kementerian agama serta pemerintah daerah. Waktu penelitian adalah 15 hari, yaitu dari tanggal 22 Maret s.d. 3 April 2014. Setelah pengumpulan data melalui kajian di lapangan, selanjutnya dilakukan analisis data. Analisis data dimulai dengan menelaah seluruh data yang tersedia. Pendekatan yang digunakan dalam analisis data adalah bersifat induktif yaitu melalui reduksi data, pengelompokkan, dan ketegorisasi data, dengan jalan abstraksi yang merupakan upaya memuat rangkuman inti, proses dan pernyataan. Sebagai tahap akhir sebelum kesimpulan dilakukan interpretasi yaitu mencoba untuk memaknai, mendiskusikan, membandingkan, mencocokkan, dengan teori yang ada.

\section{Landasan Konseptual}

1. Pelayanan Agama

Kementerian Agama RI merupakan salah satu institusi yang tidak diotonomkan karena alasan politik yang berkaiatan dengan persoalan nasionalisme dan bingkai NKRI. Agama merupakan ruang yang sangat potensial menimbulkan disintegrasi bangsa, sehingga Pemerintah Pusat diharapkan masih memiliki peran penting.Oleh sebab itu, pelayanan agama memiliki pemaknaan yang lebih mengacu pada pelayanan-pelayanan yang diberikan Kementerian Agama dan dibutuhkan oleh masyarakat sebagai user.

Penelitian ini tidak membagi pelayanan yang menjadi domain pusat atau daerah, karena hal terpenting yang akan disasar dalam riset adalah bentuk- 
bentuk pelayanan apa saja yang diberikan dan kemdian masyarakat merasa membutuhkan. Pelayanan keagamaan akan dikaji dalam 9 bagian, yakni tentang KUA dan perkawinan, kepenyuluhan, pelayanan haji, pelayanan untuk agama, Kristen, Katolik, Hindu, Budha, Konghuchu, dan kepercayaan lokal.

\section{Daerah Perbatasan}

Ada beberapa konsep tentang daerah perbatasan.Pada pasal 1 angka 6 UU No 43 tahun 2008 Tentang Wilayah Negara dijelaskan bahwa kawasan perbatasan adalah bagian dari Wilayah Negara yang terletak pada sisi dalam sepanjang batas wilayah Indonesia dengan negara lain, dalam hal Batas Wilayah Negara di darat, Kawasan Perbatasan berada di kecamatan. Termasuk istilah yang ada di Perpres 78 tahun 2005 tentang pengelolaan pulaupulau kecil terluar, 92 pulau terluar yang dimiliki Indonesia tersebut digunakan sebagai titik dasar dalam menetapkan garis batas wilayah NKRI. Ini artinya, titik persoalannya adalah batas-batas fisik antara negara Indonesia dengan Negara tetangga.

Tetapi riset ini tidak untuk menganalisis batas-batas fisik antarnegara, tetapi bagaimana batas itu sendiri telah melampaui persoalanpersoalan fisik.Kehidupan masyarakat daerah perbatasan memiliki system dan pemaknaan yang silang kebudayaan, sehingga ruang-ruang social, budaya, ekonomi, dan agama menjadi bagian yang saling bersentuhan antarnegara. Kedua negara dalam batas-batas fisik tersebut, seolah-olah hadir secara bersamaan.Masyarakat menggunakan dua kebudayaan secara bersama-sama. Tidak adanya kekuatan dominan yang berhak mengatur pergaulan antarbudaya dan antarnegara di daerah perbatasan, dalam hal ini kekuatan negara yang represif, merupakan peluang tersendiri jika disikapi secara tepat. Meminjam istilah François Lyotard (2004), masyarakat di daerah perbatasan relatif terbebas dari bercokolnya "narasi besar" yang berwatak totaliter. Pada ranah praktis, tidak adanya kekuatan dominan juga memberi peluang bagi terjadinya persilangan kategori-kategori identitas ketika setiap pihak ditemukan dalam kepentingan yang sama. Dalam kondisi seperti ini, in-group favoritism dan outgroup derogationakan berkurang.Identitas sosial menjadi lebih mudah ditembus sehingga memungkinkan terciptanya identitas hybrid. Identitas hybrid merupakan identitas baru yang terbentuk dari persilangan kategori-kategori sosial yang didasari atas kesadaran untuk mencari simpul kerja sama yang mutual dalam ruang publik. Ketika individu menyandang banyak identitas, berarti dia memiliki dimensi sosial-psikologis yang banyak

Dalam kacamata kebudayaan, identitas hybrid tidak menjadi persoalan, karena kehidupan global memang mengandung konsekuensi hilangnya batas-batas kebudayaan antarnegara. Namun, dalam konteks pelayanan public dan birokrasi, persoalan ini menjadi sangat penting, terlebih jika dikaitkan dengan nasionalisme keindonesiaan yang sedang berubah. Oleh sebab itu, dalam riset ini daerah perbatasan secara fisik tidak hanya berbasis kecamatan, tetapi daerah perbatasan akan diperluas hingga tingkat kabupaten/kota. Bahkan secara sosiologis dan antropologis, wilayah ini bisa lebih melebar, dengan melihat implikasi-implikasi social, budaya, dan agama lebih luas.

\section{Kondisi Umum Kabupaten Sanggau}

Secara administratif, Kabupaten Sanggau yang terletak di Provinsi Kalimantan Barat ini terdiri atas 15 
kecamatan, yaitu:Kapuas, Mukok, Noyan, Jangkang, Bonti, Beduwai, Sekayam, Kembayan, Parindu, Tayan Hulu, Tayan Hilir, Balai, Toba, Meliau, dan Entikong. Dari 15 kecamatan tersebut, dua di antaranya yaitu Kecamatan Sekayam dan Entikong merupakan kawasan perbatasan dengan Negara Malaysia. Kabupaten ini telah menjadi target program Pengembangan/peningkatan kualitas Kawasan Strategis dikarenakan memiliki wilayah perbatasan darat RI dan jantung Kalimantan (Heart of Borneo).

Secara demografis, berdasarkan data kependudukan Kabupaten Sanggau, jumlah penduduk pada tahun 2013 tercatat sebanyak 479.431 jiwa dengan laju pertumbuhan sebesar 1,67 Persen per tahun. (Data Disdukcapil, Kabupaten Sanggau, 2015). Jumlah penduduk terbesar terdapat di Kecamatan Kapuas denganjumlah penduduk sebanyak 90.515 jiwa sedangkan jumlah penduduk yang terkecil terdapat di Kecamatan Noyan dengan jumlah penduduk sebanyak 11.348 jiwa. Sedangkan jumlah penduduk menurut agama terdiri atas: 1). Islam (159.457 jiwa); 2). Kristen (76.293 jiwa); 3). Katolik (236.760 jiwa); 4). Hindu (230 jiwa); 5). Budha (3.769 jiwa); 6). Konghuchu (81 jiwa); dan Aliran Kepercayaan (2.841 jiwa). Katolik merupakan agama mayoritas di Kabupaten Sanggau yang pengikutnya tersebar di seluruh kecamatan. Sedangkan Islam menempati posisi kedua dari total penduduk di Kabupaten Sanggau yang mayoritas terdapat di Kecamatan Kapuas (51.366 jiwa) dan paling sedikit pengikutnya terdapat di Kecamatan Noyan (513 jiwa).

Namun demikian, sampai saat ini kepadatan penduduk Kabupaten Sanggau rata-rata baru 32 jiwa per km2. Jumlah kepadatan penduduk terbesar adalah Kecamatan Kapuas yakni 57 jiwa per kilometer persegi dan paling jarang penduduknya adalah kecamatan Toba sebesar 11 jiwa per kilometer persegi. Masalah pokok dalam bidang kependudukan antara lain adalah penyebaran penduduk yang belum merata, komposisi penduduk yang tidak seimbang serta arus urbanisasi dari desa ke kota, termasuk arus perlintasan dua negara. Masalah kependudukan ini pada akhirnya berpengaruh kepada pelayanan umum yang dilakukan pemerintah.

Entikong, penamaan wilayah perbukitan yang dibelah oleh Sungai Setayam ini karena berada persis di pinggir lajur sungai yang menikung (berkelok): Dari "nikung" diucapkan "nekong" kemudian dikenal Entikong. Di masa Kesultanan Sanggau, Entikong termasuk wilayah kekuasaan perwakilan Sultan Sanggau yang ditempatkan di Sekayam. Pada saat itu Entikong belum berpenghuni karena orang Melayu dan Dayak masih memilih Sekayam sebagai tempat tinggal. Entikong juga pernah dijadikan tempat pembuangan para pengikut Soemokil, tokoh Republik Maluku Selatan, tepatnya Entikong bagian utara sungai Sekayam.

Hingga tahun 1957, penduduk yang berdiam di Entikong hanya ada 6 kepala keluarga. Hal ini sangat mungkin terjadi sebab pada masa itu tidak ada akses jalan darat menuju Entikong. Perjalanan dari Entikong ke Sanggau dibutuhkan waktu 9 hari dan Entikong ke Sekayam bisa dicapai selama dua malam melalui jalur sungai. Pembangunan Entikong dimulai setelah TNI berhasil menumpas eks pasukan Soemokil yang bergabung dengan PKI, pada tahun 1963-1965. Pada saat itu TNI berbasis di "Selatan Sungai" sedangkan PKI berada di sebelah "Utara Sungai". Presiden Soekarno pernah berkunjung ke Entikong pada saat akan meletusnya pemberontakan eks pasukan Soemakil. Mayjen Soeharto juga pernah memimpin penumpasan PKI di Entikong pada 1965. Pada tahun 1971, TNI mulai membangun jalan darat dari arah jembatan Entikong sampai Bonti ke arah 
Kecamatan Parindu. Sedangkan yang merintis jalan perbatasan dari jembatan Entikong menuju Tebedu adalah Australia pada tahun 1977. Walaupun demikian secara umum TNI yang memiliki andil besar terhadap pembangunan Entikong.

Sejak pembangunan jalur darat tersebut, banyak masyarakat di Kabupaten Sanggau dan daerah lainnya melakukan hijrah ke Entikong, baik untuk berbisnis maupun tinggal menetap di sana. Hubungan antara masyarakat Entikong dengan masyarakat perbatasan Malaysia pun berlangsung semakin intens. Hal ini mendorong pemerintah RI dan Malaysia membuat kesepakatan pada tahun 1979 agar masing-masing negara membangun kawasan perbatasan. Kedua negara juga bersepakat untuk membolehkan jualbeli antara penduduk dan keluar masuk barang dari masing-masing wilayah asal tidak lebih dari 600 ringgit. Oleh karena itu, kedua negara kemudian bersepakat untuk menyediakan 5 buah bus di masing-masing perbatasan negara. Inilah tonggak awal pembangunan perbatasan di Entikong.

Namun demikian, faktanya pembangunan Entikong tetap saja tidak secepat pembangunan perbatasan Negeri Bagian Serawak, Malaysia meskipun Entikong telah menjadi daya tarik tersendiri bagi warga negera Indonesia yang ingin melintas ke Malaysia, baik untuk bekerja, berbelanja, maupun usaha lainnya. Akibatnya laju pertumbuhan penduduk rata-rata di wilayah Entikong meningkat lebih cepat yakni $9,51 \%$ per tahun, dibandingkan dengan Kabupaten Sanggau yang hanya $1,44 \%$ per tahun.

Kondisi ini menyebabkan penduduk yang menetap di Entikong tidak lagi hanya suku Melayu dan Dayak, melainkan suku-suku lainnya di Indonesia. Keberadaan multi etnis di Entikong berdampak kepada pergumulan yang harmonis antar agama dan budaya serta ekonomi penduduknya.
Hal ini sesuai dengan motto Kecamatan Sanggau: "Dari manapun, suku apapun, agama apapun, jadilah warga yang baik dan bertanggung jawab". Di Entikong, agama mampu beradaptasi dengan budaya lokal, begitu pula sebaliknya. Agama mampu berkembang dan bersinggungan dengan budaya setempat tanpa ada konflik yang berarti. Islam, Kristen, Katolik dan agama lainnya bisa berkembang dengan baik dan penganut masing-masing agama mampu hidup bersanding secara harmonis. Di bidang ekonomi, pertumbuhannya menunjukkan angka yang cukup signifikan yaitu sekitar $5 \%$ per-tahunnya. Peluang kerja juga terbuka luas, bukan saja bagi penduduk asli Entikong, tetapi juga pendatang lainnya.

Namun demikian, di sisi lain, dampak keterbukaan kawasan perbatasan Entikong dari penduduk pendatang baru tidak luput memicu persoalan yang baru pula. Di bidang agama, teridentifikasi beberapa masalah, antara lain: 1). Pembinaan agama kurang maksimal bagi segenap lapisan masyarakat yang berdampak kepada merosotnya nilai agama dan budaya, seperti masalah Narkoba, praktik "kumpul kebo" dan prostitusi, dan lain sebagainya; 2). Munculnya paham Islam trans-nasional di daerah perbatasan. (Muhammad Ibbas, Tokoh Islam Entikong-Sekayam. Wawancara. 27 Maret 2014).

Sementara di bidang sosial, teridentifikasi beberapa masalah, di antaranya; 1). Masalah perkawinan dan keluarga akibat mobilitas pelintas batas dari Malaysia ke Indonesia dan sebaliknya yang cukup tinggi. Setiap harinya terdapat 6.000 orang yang melalui PPLB (Pos Pengelola Lintas Batas). Di Entikong mudah ditemukan praktik kawin kontrak, poligami liar, praktik poliandri dan kumpul kebo (bojo-bojo-an); 2). Masalah sengketa lahan hutan, perkebunan, dan pemukiman serta lahan kuburan akibat ketidakpahaman masyarakat pendatang 
dengan adat pertanahan penduduk asli Suku Dayak. Dalam adat mereka ada yang disebut lahan kuning (lahan yang hanya dapat ditempati tidak bisa dimiliki), dan lahan hijau (lahan yang dapat ditempati dan miliki). Kebutuhan perluasan pemukiman bagi masyarakat pendatang sering berhadapan dengan adat itu yang menyebabkan sengketa lahan.

Adapun di bidang ekonomi, terdapat masalah krusial yang perlu ditangani, yaitu: 1). Masalah lalu lintas keluar masuknya barang melalui PPLB (Pos Pengelola Lintas Batas)-nya. Pasalnya barang-barang komoditi asal Malaysia, meliputi Sembilan bahan pokok (Sembako) termasuk gasnya beredar luas di kalangan masyarakat Entikong dan sekitarnya. Masyarakat Entikong tidak pernah merasakan keresahan akibat kenaikan Sembako ataupun bahan bakar minyak dan gas sebagaimana yang dirasakan oleh masyarakat di seluruh wilayah Indonesia; 2). Persaiangan penguasaan sumbersumber ekonomi antar kelompok dan suku sudah mulai muncul secara laten di kawasan perbatasan. Hal ini sebagai akibat tidak langsung dari aktifitas ekonomi di kawasan perbatasan Entikong yang "tidak sehat" antara lain berupa penguasaan oleh suku tertentu terhadap bisnis ekspedisi, money changer, lahan property, taxi, penampungan TKI sampai bisnis prostitusi (Wawancara dengan Awal Yuda Setiawan, Badan Nasional Pengelola Perbatasan daerah Sanggau, 24 Maret 2014).

\section{Temuan dan Pembahasan}

1. Pelayanan Keagamaan di kawasan Perbatasan

Kementerian Agama sebagai aparatur pemerintah memiliki posisi dan tugas fasilitator dalam membangun iklim keagamaan yang kondusif bagi perkembangan masyarakat yang dinamis, progresif, toleran dan damai diatas dasar nilai keagamaan dan kekayaan budaya yang berkeadaban (Sudijono: 2000). Untuk menjabarkan tugas itu, maka Keputusan Menteri Agama (KMA) Nomor 1 Tahun 2001 telah menggariskan fungsi Kementerian Agama meliputi empat masalah pokok, yaitu: 1). Memperlancar pelaksanaan pembangunan di bidang keagamaan; 2). Membina dan mengoordinasikan pelaksanaan tugas serta administrasi Kementerian; 3). Melaksanakan penelitian dan pengembangan, terapan pendidikandan pelatihan tertentu dalam rangka mendukung kebijakan di bidang keagamaan; dan 4). Melaksanakan pengawasan fungsional.

Secara khusus berkaitan dengan fungsi pelaksanaan pembangunan di bidang keagamaan, Kementerian agama telah menetapkan program pelayanan keagamaan. Pelayanan keagamaan merupakan bagian dari pelayanan umum, yaitu segala kegiatan yang dilaksanakan oleh penyelenggara pelayanan publik sebagai upaya pemenuhan kebutuhan penerima pelayanan, maupun dalam rangkapelaksanaanketentuan perundangundangan. Dasar yang utama pelayanan keagamaan di Indonesia adalah Sila ke-1 Pancasila dan Pasal 27 UUD Tahun 1945. Pelayanan keagamaan di Indonesia dapat dilakukan oleh penyelenggara pelayanan publik, baik dari unsur pemerintah maupun unsur sosial-kemasyarakatan. Hal ini menjadi keunikan tersendiri sebab walaupun Indonesia bukan negara agama tetapi peran serta agama dalam sejarah pembentukan negara tidak bisa dinafikan. Oleh sebab itu, Indonesia tidak dapat serta-merta membiarkan urusan agama dalam ranah privat tetapi juga terlibat menyelenggarakan pelayanan agama sesuai dengan ketentuan perundangundangan. Ruang lingkup pelayanan keagamaan yang dilaksanakan negara menurut undang-undang meliputi: perkawinan Islam, zakat/infaq/sedekah/ 
wakaf, haji, pendidikan keagamaan, dan sebagainya. Di luar itu pelayanan keagamaan diserahkan kepada lembaga sosial keagamaan.

Dalam konteks ini, negara dalam menyelenggarakan pelayanan keagamaan telah membentuk unit pelayanan keagamaan melalui Kementerian Agama mulai di tingkat Pusat, Wilayah Provinsi, dan Kabupaten, dengan ujung tombaknya Kantor Kementerian Agama Kabupaten/ Kota serta Kantor Urusan Agama (KUA). Di tingkat Kabupaten Sanggau pelayanan keagamaan dilakukan oleh Satuan Kerja Kementerian Agama Kabupaten yang memiliki struktur meliputi: 1). Kepala Kantor; 2). Kepala Tata Usaha; 3). Seksi Mapenda; 4). Seksi Pendidikan Islam (PAIS); 5). Seksi Haji dan Umrah; 6). Seksi Urais; 7). Seksi Penyelenggara Syariah; 8). Penyelengga Katolik; 9). Penyelenggara Kristen.

Mengenai keberadaan struktur "Penyelenggara" di Kementerian Agama Kabupaten Sanggau ini, sebagai penganut agama mayoritas di Kabupaten Sanggau, tokoh Katolik dan Kristen mengeluhkan diskriminasi pada aspek struktur Kementerian Agama Kabupaten Sanggau: Mengapa pelayanan agama Katolik dan Kristen diselenggarakan oleh Penyelenggara, bukan Seksi?

Untuk mengukur pemenuhan kebutuhan pelayanan pemerintah melalui Menteri Pendayagunaan Aparatur Negara telah menetapkan Keputusan Menpan No. Kep/25/M. PAN/2004 tentang pedoman umum penyusunan indeks kepuasaan masyarakat unit pelayanan instansi pemerintah yakni: 1). Prosedur pelayanan; 2). Persyaratan pelayanan; 3). Kejelasan petugas pelayanan; 4). Kedisiplinan petugas pelayanan; 5). Tanggung jawab petugas pelayanan; 6). Kemampuan petugas pelayanan; 7). Kecepatan pelayanan; 8). Keadilan mendapatkan pelayanan; 9). Kewajaran biaya pelayanan; 10). Kepastian biaya pelayanan; 11). Kenyamanan lingkungan, dan 11). Keamanan lingkungan. (Wawancara dengan Moch. Natsir, Kepala Kantor Kementerian Agama Kabupaten Sanggau, 24 Maret 2014).

2. Pelayanan Keagamaan di KUA Entikong-Sekayam

Pelayanan keagamaan di kawasan perbatasan Entikong diselenggarakan oleh KUA dan Kantor Kementerian Agama Kabupaten Sanggau. Ditinjau dari infrastruktur yang ada di wilayah Entikong dan Sekayam sudah berdiri KUA. Sementara Kantor Kementerian Agama Kabupaten Sanggau sudah berdiri sejak lama, dan bahkan ada keinginan untuk dipindahkan ke kawasan baru pemerintah daerah di wilayah Timur Sanggau.

Kondisi fisik bangunan KUA di wilayah perbatasan relatif sudah permanen dan dialiri listrik PLN maupun PDAM, meskipun belum terpasang kabel telepon yang menyebabkan tidak berjalannya progam SIMKAH. Masalah lain yang dihadapi masing-masing KUA adalah kurangnya tenaga (SDM) sebagai ujung tombak pelayanankeagamaan.KUA sudah berdiri di 15 wilayah kecamatan, termasuk di Kecamatan Noyan yang penduduk muslimnya hanya 70-80 KK. Tetapi tenaga KUA sangat terbatas. Dari 15 KUA hanya ada 3 KUA yang memiliki staf. Pada umumnya Kepala KUA bekerja sendiri. Bahkan ada 2 KUA yang tidak memiliki kepala kantor, diantaranya KUA Entikong yang hanya memiliki seorang staf. Pelayanan pencatatan nikah pada KUA Entikong digabung dengan KUA Sekayam yang hanya memiliki Kepala KUA dan seorang staf. Kondisi yang sama juga terjadi di KUA Noyan dan KUA Beduai yang dirangkap oleh seorang Kepala KUA, yaitu Tafsirudin sebagai Kepala KUA Noyan, karena Kepala KUA Beduai, Jamiun sudah lama menderita 
sakit. (Wawancara dengan Moch. Natsir, Kepala Kantor Kementerian Agama Kabupaten Sanggau, 24 Maret 2014).

Sebelum pemekaran Kecamatan Entikong pada 1997, pelayanan pencatatan nikah diselenggarakan KUA Sekayam, bahkan sampai tahun 2000 KUA Entikong baru beroperasi. Kepala KUA maupun staf KUA yang ditugasi sudah bergontaganti: Thoyib Shalahudin Al-Ayyubi (2000) M. Jafar (2002-2006), H. Nasri (2006-2011), Raini (2012), dan sekarang Eko Setyo Nugroho (2014). Dengan demikian, pergantian petugas KUA Entikong tidak selalu terisi oleh petugas yang menggantikan, misalnya tahun 2000-2002 terjadi kekosongan petugas KUA, dan 2012-2014 terulang peristiwa yang sama. Bahkan pelayanan KUA Entikong selama ini hanya dilaksakan oleh satu orang pegawai, baik selaku Kepala KUA maupun hanya sebagai staf KUA. Padahal idealnya KUA sebagai ujung tombak Kementerian agama memiliki seorang Kepala KUA, seorang TU/Bendahara dan dibantu minimal 6 (enam) orang staf, sesuai dengan jenis pelayanannya, yaitu: 1). Pelayanan bidang organisasi dan ketatalaksanaan; 2). Pelayanan teknis dan administrasi nikah/rujuk; 3). Pelayanan Teknis dan Administrasi, Kependudukan, Keluarga Sakinah dan Kemitraan; 4). Pelayanan Teknis dan Administrasi Kemasjidan; 5). Pelayanan Teknis dan Administrasi ZIS dan Wakaf; 6). Pelayanan Informasi tentang Madrasah, Pondok Pesantren, Haji dan Umrah; dan 7). Pelayanan Lintas Sektoral. Sebagai akibat minimnya petugas di KUA Entikong, hanya jenis pelayanan administrasi nikah/rujuk saja yang berfungsi efektif, sedangkan jenis layanan lainnya tidak berjalan secara normal (Wawancara dengan Thoyib Salahudin Al-Ayyubi, Mantan Kepala KUA Entikong dan Sekayam, 21 Maret 2014).
Secarafaktual pelayanankeagamaan yang dilakukan KUA Entikong dapat dideskripsikan sebagaimana berikut:

Pertama, Pelayanan Bidang Organisasi dan Ketatalaksanaan yangjenis pelayanannya mencakup: 1). Pembinaan karyawan/ti dalam hal pelayanan pada masyarakat; 2). Pembinaan P3N; 3). Penyerahan formulir NR (N1 s.d. N6); 4). Pemberian Rekomendasi permohonan bantuan masjid; 5). Pemberian informasi data keagamaan; dan 6). Pemberian surat keterangan masuk Islam. Jenis pelayanan ini baru sedikit yang dilakukan di KUA Entikong karena sempat terjadi kekosongan petugas, sedangkan petugas yang baru diangkat kurang berpengalaman dan belum dikenal banyak oleh masyarakat. Bahkan banyak yang menganggap Kemenag kurang serius dalam penempatan pegawai KUA Entikong karena yang ditugasi bertempat tinggal di pusat Kabupaten Sanggau yang jaraknya kurang lebih $120 \mathrm{~km}$ dengan waktu tempuh 3 jam. (Wawancara dengan Moch. Natsir, 24 Maret 2014).

Kedua, Pelayanan Teknis dan Adminstrasi Nikah/Rujuk yang jenis pelayanannya mencakup: 1). Penyerahan formulir pendaftaran pernikahan (N7); 2). Pemberitahuan biaya nikah; 3). Pengumuman jadwal pernikahan; 4). Penasehatan catin; 5). Pengawasan dan pencatatan akad nikah; 6). Konfirmasi waktu pelaksanaan Nikah (N7); 7). Penyerahan kutipan akta nikah kepada pengantin (NA); 8). Pemberian rekomendasi nikah; 9). Legalisir kutipan akta nikah; 10). Pemberian keterangan mengetahui status belum menikah; dan 11). Pemberian duplikat kutipan akta nikah (DN). Secara umum jenis pelayanan ini sudah dipraktikkan sesuai dengan kapasitas staf KUA sebagai penerima pendaftaran nikah. Selebihnya, layanan ini dialihkan kepada Kepala KUA Sekayam. Dalam setahun ratarata pendaftaran perkawinan di KUA 
Entikong hanya 20 kali. Jumlah ini sangat sedikit jika dibandingakan dengan jumlah penduduk Muslim di Entikong. Secara statistik, jika perbandingan usia nikah adalah 1:1000 penduduk, maka dengan penduduk muslim sebanyak 14.047 jiwa semestinya jumlah peristiwa perkawinan adalah 14 kali perbulan atau 168 kali pertahun. Ini menandakan terjadinya praktik perkawinan yang tidak tercatat. (Wawancara dengan Moch. Natsir, 24 Maret 2014).

Ketiga, Pelayanan Teknis dan Administrasi, Kependudukan, Keluarga Sakinah dan Kemitraan yang jenis pelayanannya mencakup: 1). Pemberian bimbingan perkawinan kepada calon pengantin;2).PembinaanFikihMunakahat dan UU No.1 Tahun 1974 Tentang perkawinan dan PP No.9 Tahun 1975; 3). Penyelenggaraan Suscatin (Kursus Calon Pengantin); 4). Pembinaan Keluarga Sakinah; 5). Pemilihan Keluarga Sakinah; 6). Konsultasi krisis rumah tangga; 7). Konsultasi waris, wali dan hibah; dan 8). Penyerahan data umat beragama ke Kantor Kementerian Agama. Di KUA Entikong tidak semua jenis pelayanan ini diberikan kepada masyarakat, padahal di wilayah perbatasan sering terjadi praktik kawin siri, kawin kontrak, poligami dan poliandri liar, dan sebagainya. Termasuk layanan suscatin yang dilakukan dalam waktu bersamaan dengan prosesi akad nikah karena alasan domisili calon pengantin jauh dari KUA. (Wawancara dengan Moch. Natsir, 24 Maret 2014).

Keempat, Pelayanan Teknis dan Administrasi Kemasjidan yang jenis pelayanannya meliputi: 1). Pemberian informasi data rumah ibadah (Masjid, Surau dan Musholla); 2). Pembinaan adminstrasi terhadap pengurus masjid dan perpustakaannya; 3). Pendistribusian buku pedoman kemasjidan dan pedoman diklat; 3). Kordinasi dengan pengurus masjid; 4). Penentuan masjid binaan; dan 5). Penentuan masjid teladan. Kegiatan ini pernah dilakukan di KUA Entikong pada masa Thoyib dan Nasri dan sudah tidak dilakukan lagi selama tiga tahun sampai saat ini. Padahal perkembangan terakhir di kawasan Entikong, seiring dengan pertambahan jumlah penduduk beragama Islam, telah berdiri tempattempat peribadatan, majelis taklim, TPA, dan lain-lain. (Wawancara dengan Moch. Natsir, 24 Maret 2014).

Kelima, Pelayanan Teknis dan Administrasi ZIS dan Wakaf yang jenis kegiatannya meliputi: 1). Sosialisasi UU Zakat No. 38 Tahun 1999; 2). Penyuluhan tentang Zakat, Infaq dan Shadaqah; 3). Penyampaian SK Pembentukan BAZ UPZ kelurahan; 4). Penyaluran bantuan dana bergulir BAZ; 5). Pengumpulan Zakat, Infaq, dan Shadaqah; 6). Pemberian informasi tanah wakaf; 7). Monitoring stok blanko tanah wakaf; 8). Inventarisasi tanah wakaf yang bermasalah; 9). Penyelesaian sertifikasi tanah wakaf; 10). Pembinaan Nadzir, Pembuatan dan penyerahan salinan AIW / APAIW; 11). Pelayanan pengaduan tanah wakaf dan pemberian solusi terhadap tanah wakaf yang bermasalah serta Penjelasan ZIS bagi jamaah haji. Hampir semua jenis kegiatan ini tidak dilakukan di KUA Entikong tetapi sebagian dilakukan langsung melalui Kantor Kementerian Agama Kabupaten Sanggau. Alasannya karena potensi zakat, infak, shodaqoh, dan wakaf di Entikong belum begitu besar dan baru ada satu masjid yaitu Al-Muhajirin yang mengelola ZIS dan administrasi keuangannya cukup baik dan accountable. Pendapatannya pertahun rata-rata 100 juta rupiah. Wakaf di Entikong juga baru ada 5 lokasi seluas 11.768 yang diperuntukkan untuk masjid, surau, dan kuburan. Namun demikian ada kecenderungan masyarakat Entikong mulai tergugah untuk mendayagunakan ZIS dan wakaf, dengan terbentuknya Badan Fardhu Kifayah Entikong yaitu badan yang bergerak di bidang sosial keagamaan dan kewirausahaan. 
(Wawancara dengan Eko Setyo Nugroho, Pelaksana Tugas KUA Entikong, 21 Maret 2014).

Keenam, Pelayanan Informasi tentang Madrasah, Pondok Pesantren, Haji dan Umrah yang jenis kegiatannya meliputi: 1). Penjelasan izin operasional; 2). Penjelasan legalisasi ijazah madrasah; 3). Penjelasan permohonan bantuan pondok pesantren; 4). Penjelasan pendaftaran haji dan umrah. Kegiatan ini hanya dilakukan di Kantor Kementerian Agama Kabupaten Sanggau karena pertimbangan pengguna pelayanan masih sangat sedikit. Di Kecamatan Entikong hanya ada satu madrasah yaitu MI AlIstiqamah, Pondok pesantren belum ada, dan jumlah jemaah haji pertahun ratarata 2 orang. Kondisi ini berbeda dengan wilayah KUA Sekayam yang terdapat 5 (lima) madrasah (MI Al-Wardah, MI alRaudah, MTsN Bale Karangan, MTs AlMizan dan MA al-Mizan), 2 pesantren (Al-Mizan dan Miftahul Hidayah), dan jumlah jemaah haji rata-rata 7 orang pertahun. (Wawancara dengan Moch. Natsir, 24 Maret 2014).

Ketujuh, Pelayanan Lintas Sektoral yang jenis pelayanannya meliputi: 1). Pemberian pengantar imunisasi ke Puskesmas bagi calon pengantin; 2). Penyuluhan narkoba bekerja sama dengan Subdin Kesehatan, Polsek dan Kecamatan; 3). Pembinaan keluarga sakinah bekerja sama dengan Kanwil Kemenag, PLKB, Puskesmas dan PKK; 4). Penyelenggaraan Jumat bersih bekerja sama dengan pengurus masjid dan surau; 5). Pemberian santunan kepada yatim piatu bekerjasama dengan BAZ; 6). Pembinaan kerukunan umat beragama bekerja sama dengan FKUB. Jenis pelayanan ini hanya sebagian kecil yang dilakukan di KUA Sekayam, terutama yang berhubungan langsung dengan pendaftaran nikah, sedangkan sebagian besar jenis pelayanan dilakukan langsung melalui Kantor Kementerian Agama
Kabupaten Sanggau. (Wawancara dengan Moch. Natsir, 24 Maret 2014).

Ketidakefektifan pelayanan keagamaan KUA Entikong akibat ketersediaan SDM menyebabkan KUA Entikong sulit memenuhi 14 unsur pelayanan publik berdasarkan indeks kepuasan masyarakat. Sebagai contoh jenis pelayanan Teknis dan Adminstrasi Nikah/Rujuk yang dianggap paling dominan dilaksanakan KUA Entikong, akan tetapi secara infrastruktur banyak yang tidak terpenuhi. Hal ini dibuktikan dengan ketiadaan papan informasi alur pelayanan teknis dan administrasi Nikah/ Rujuk, kelengkapan kantor masih sangat minim dan kurang nyaman, dan lain-lain. Gambaran infrastruktur KUAEntikong ini dapat menjadi indikasi bahwa pelayanan keagamaan di perbatasan masih jauh dari harapan.

3. Pelayanan Penyuluh Agama Fungsional di Entikong

Penyuluh Agama Fungsional diberi tugas, wewenang, tanggungjawab, dan hak secara penuh oleh pejabat yang berwenang untuk melaksanakan Bimbingan dan Penyuluhan Agama dan Pembangunan pada masyarakat melalui bahasa agama. Untuk sementara ini regulasi penyuluh agama fungsional "menginduk" pada Keputusan Bersama Menteri Agama dan Kepala BKN No. 574 Tahun 1999. Penyuluhan agama merupakan salah satu bentuk satuan kegiatan yang memiliki nilai strategis, khususnya dalam menjalankan fungsi memperlancar pelaksanaan pembangunan di bidang keagamaan, termasuk di kawasan perbatasan seperti Entikong dan Sekayam. Sasaran penyuluhan agama adalah para penduduk yang mendiami wilayah sebagai penerima layanan agama di tempat para penyuluh bertugas. 
Di Entikong dan Sekayam, penduduk yang terlayani secara keagamaan hanya umat Katolik, Kristiani, dan Muslim sebagai kelompok potensial di daerah perbatasan. Hanya saja dalam kenyataannya penyuluhan agama masih menghadapi banyak permasalahan krusial, yang paling pokok ialah: SDM, letak geografis, kondisi masyarakat sebagai obyek Bimbingan dan Penyuluhan Agama (BPA), penggunaan Teknologi Informasi dan Komunikasi, Masa kerja penyuluh, dan dana operasional kegiatan BPA.

4. Bimbingan dan Penyuluhan Agama Islam

Penganut agama Islam di kawasan perbatasan Entikong dan Sekayam totalnya berjumlah 20.083 jiwa. Pemeluk agama Islam terkecil berada di Desa Nekan (6 orang), Desa Pala Pasang (4 orang), dan Desa Suruh Tembawang (18 orang). Ketiga desa berada di wilayah Kecamatan Entikong dengan jarak terjauh $42 \mathrm{~km}$ yang hanya bisa dicapai dengan menggunakan motor air. Sarana peribadatan umat Islam yang berdiri terdiri atas bangunan masjid (27 bangunan), surau dan mushalla (22 bangunan) dalam kondisi permanen dan semi permanen serta darurat. Tidak semua lahan bangunan mesjid dan mushalla berstatus wakaf. Dari 49 bangunan mesjid dan musalla di Entikong dan Sekayam hanya 30 lahan yang berstatus wakaf, selebihnya masih menjadi milik perorangan.

Di setiap masjid/mushalla terdapat imam masjid/mushalla dan ustadz/guru agama, namun tidak terdata berapa jumlah keseluruhannya. Mereka tidak ditugasi khusus dan tidak mendapatkan gaji tetap seperti imam/ustadz di wilayah Serawak Malaysia, tetapi lebih dimotivasi panggilan jiwa dan agama. Tidak banyak tokoh agama di kawasan perbatasan yang berlatar belakang pendidikan agama seperti pesantren atau madrasah. Kebanyakan mereka dari generasi tua yang belajar agama secara turunan bukan melalui lembaga pendidikan Islam, sehingga dari segi bacaan al-Quran dan penguasaan ilmu-ilmu keislaman masih rendah. Sebagai contoh seorang imam masjid membaca ayat "ghairil maghzhubi 'alaihim" dengan bacaan "rairil marzdubi "alaihim" dan saat tahlilan seharusnya membaca tarqiq (tipis) lafal "Bihillah, Yaghfiru limayyasya" tetapi dibaca tafkhim (tebal) mejadi "Bihilloh".

Pandangan keagamaan mereka juga masih kolot, seperti pandangan imam harus dari orang tua; zakat, infaq, sedekah hanya diperuntukkan pengurus masjid; perwalian anak angkat oleh orang tua angkat seolah menjadi anak kandung; dan wakaf kuburan hanya untuk pemakaman orang-orang yang dikenal muslim dan taat beragama. Seperti dituturkan oleh salah seorang pengurus Mesjid Al-Muhajirin, M. Shodiq Nur Fath, pernah terjadi satu kasus meninggalnya seorang TKI karena mengidap masalah kejiwaan, yang belakangan diketahui bernama Sonhaji asal Magelang yang ditolak Pengelola kuburan wakaf Entikong karena alasan tidak jelas asal usulnya. Mayatnya sempat dibawa ke kantor kepolisian dan hendak dibakar oleh warga karena sudah didiamkan 2 hari dan akhirnya karena ketidakjelasan identitas tersebut mayat Sonhaji dikubur di tepi Sungai Entikong. Keberadaan tokoh agama yang umumnya berpandangan kolot ini di sisi lain cukup efektif "menghalau" laju pergerakan gerakan Islam Transnasionalis dan gerakan puritanisme Islam, seperti SalafiWahabi di kawasan perbatasan. Semenjak tahun 2010 telah muncul kelompok Islam yang suka membid'ahkan dan menyesatkan kelompok Islam lain di Entikong tetapi dengan sendirinya tertolak oleh masyarakat karena pengaruh kelompok Orang Tua itu. 
Selain pelayanan agama yang dilakukan secara suka rela oleh tokoh informal, di Entikong dan Sekayam juga terdapat Penyuluh Agama Fungsional. Dalam Daftar Penyuluh Agama Islam Honorer Kementerian Agama Kabupaten Sanggau Tahun 2013 terdapat 8 orang yang ditugaskan di Entikong dan Sekayam dari total 84 orang (4 PNS) penyuluh agama Islam se-Kabupaten Sanggau. Kedelapan tenaga BPA di Entikong dan Sekayam berstatus honorer, 7 orang berpendidikan SLTA dan DII hanya 1 orang. Hanya saja peran mereka tidak dirasakan masyarakat karena berbagai alasan, di antaranya: Pertama, alasan letak geografis yakni umumnya tenaga BPA bukan berasal dari daerah bimbingannya. Di Entikong, misalnya, dari 3 orang BPA hanya 1 orang, yaitu Yusman, yang berasal dan menetap di Entikong. Dua orang lagi tidak menetap di Entikong, padahal jarak Entikong dengan daerah terluar lebih dari $20 \mathrm{~km}$. Selain itu, meskipun umumnya obyek BPA masyarakat Islam di pusat kecamatan tetapi terdapat pula keluarga Muslim di pedalaman, seperti di desa Suruh Tambawang, yang sulit dijangkau dengan menggunakan transportasi darat.

Kedua, kondisi masyarakat Entikong dan Sekayam sebagai obyek Bimbingan dan Penyuluhan Agama (BPA) yang secara kultural lebih mengutamakan generasi tua sebagai kiblat beragama dan berkonsultasi masalah agama. Tenaga BPA pada umumnya tidak berfungsi optimal karena pelayanan keagamaan ditangani Kelompok Orang Tua. Akibatnya tenaga BPA lebih banyak berfungsi sebagai guru agama Taman Pendidikan Al-Qur'an daripada menjalankan tugas sebagai petugas Bimbingan dan Penyuluhan Agama dan Pembangunan pada masyarakat melalui bahasa agama secara partisipatif dan transformatif. Hal ini dikeluhkan sendiri oleh seorang penyuluh, Yusman, yang tidak mengerti apa yang semestinya dilakukan dalam kegiatan BPA.
Ketiga, penggunaan Teknologi Informasi dan Komunikasi. Secara khusus basis kelompok Islam di Kecamatan Entikong dan Setayam berada di desa atau kota kecil pusat kecamatan yang relatif baik mendapatkan akses teknologi informasi dan komunikasi. Sekalipun jaringan telepon kabel belum memadai tetapi jaringan telepon seluler sudah terjangkau. Masyarakat di sana juga telah menggunakan teknologi parabola untuk menangkap siaran televisi nasional dan lokal. Di samping itu, di sana terdapat stasiun transmisi pemancar RRI, hanya saja dari teknologi informasi dan komunikasi yang tersedia tidak ada yang dimanfaatkan untuk kegiatan DPA termasuk tidak ada pemanfaatan RRI Entikong untuk kegiatan BPA dan acara keagamaan lainnya di bulan Ramadhan. Hal ini disebabkan ketidakmahiran tenaga BPA dalam penggunaan Teknologi Informasi dan Komunikasi, serta tidak adanyajaringan kelompok kerja penyuluh agama Islam di Kabupaten Sanggau.

Keempat, ketiadaan dana operasional kegiatan BPA kecuali mereka mendapat honor Rp. 300.000/bulan. Dengan jumlah honor itu penyuluh agama Islam kesulitan untuk melakukan kegiatan BPA di daerah pedalaman.

Secara umum daerah pedalaman tidak mendapatkan layanan penyuluhan agama Islam. Seperti diutarakan seorang pegawai BNPP, Awal Yuda Setiawan, yang pernah mendapati kelompok Islam dari suku Dayak di desa Suruh Tambawang, berjarak $42 \mathrm{~km}$ dari pusat Entikong, sedang memagari areal bangunan mushalla setempat dengan bambu agar tidak dilintasi babi milik saudara mereka sesama Dayak. Namun, keberadaan pemeluk Islam dan bangunan Mushalla di desa Suruh Tambawang ternyata tidak didapati tokoh yang ahli agama. Hal senada juga diutarakan tokoh Islam Entikong asal Sambas, Ahmad Ibbas. Menurutnya menurunkan muballigh/ 
penyuluh Islam ke daerah pedalaman lebih banyak mengundang resiko. Masyarakat pedalaman sangat kuat mempertahankan budaya leluhurnya, termasuk yang negatif. Sudah banyak muballigh/penyuluh agama yang berusaha merubah adat-istiadat itu akan tetapi mengakibatkan konflik. Ia berpendapat, lebih baik menempatkan muballigh/penyuluh di pusat kecamatan untuk memperkuat dakwah Islamiyah di daerah perbatasan.

Hal ini disebabkan anak-anak pedalaman memilih menginap di Entikong maupun Bale Karangan pada saat melanjutkan pendidikan SLTP karena alasan jarak tempuh yang jauh dari rumahnya. Lebih baik lagi jika pemerintah membangunkan pesantren atau rumah singgah untuk anak-anak pedalaman yang sedang merantau dalam rangka menimba ilmu di Entikong dan Sekayam. Dalam hal ini para muballigh/ penyuluh agama dapat difungsikan untuk membina mereka dalam lingkungan pesantren atau rumah singgah yang didirikan pemerintah. (Wawancara dengan Yusman, Penyelenggara Mantan P3N Entikong, 26 Maret 2014).

\section{Bimbingan dan Penyuluhan Agama Katholik}

Penganut agama Katolik di Entikong dan Sekayam totalnya berjumlah 27.698 jiwa dengan tempat peribadatannya sebanyak 40 gereja. Bangunan gereja bersifat permanen dan darurat yang berdiri di atas tanah milik Paroki dan di beberapa Stasi (gereja kampung) masih milik adat. Kriteria gereja permanen ialah bangunannya bertembok dan berpondasi beton, sedangkan gereja darurat yaitu bangunannya masih semi permanen yang terbuat dari papan dengan tiang berupa kayu bulat. Gereja Pusat Paroki keseluruhannya berupa bangunan permanen dan gereja Stasi sebagiannya berupa bangunan darurat. Di setiap Gereja Paroki terdapat perpustakaan Rohani sedangkan di gereja Stasi tidak ada perpustakaannya. Walaupun Gereja Paroki memiliki perpustakaan akan tetapi koleksi buku perpustakaannya masih sangat sedikit, termasuk kitab sucinya. Baik di Entikong maupun Sekayam, sudah ada pusat Paroki yang masingmasing dipimpin oleh 2 orang pastor. Selain keberadaan Pastor di pusat Paroki Entikong terdapat 5 penyuluh honorer, dan di pusat Paroki Sekayam ada 3 orang penyuluh honorer yang disebar sebagai pelayan Tuhan di desa-desa pedalaman. Semua penyuluh Katolik di Entikong dan Sekayam sudah berpendidikan Strata Satu (S1) Teologi, tetapi belum ada satupun yang berstatus PNS. Mereka berfungsi membantu pastor dalam bidang administrasi gereja, mendata jemaah gereja, dan memberikan penyuluhan atau konsultasi masalah social-keagamaan jemaatgereja di tingkatStasi. Peran mereka cukup strategis dalam memberikan bimbingan dan konsultasi umat Katolik, di saat gereja-gereja di pelosok kampung tidak semuanya mempunyai pastor.

Hanya saja keberadaan 5 orang penyuluh honorer di daerah perbatasan hingga kini dirasakan belum mencukupi untuk melayani seluruh umat Katholik. Hal ini disebabkan jangkauan wilayah di kecamatan Entikong dan Sekayam sangat jauh dan sulit dilalui dengan transportasi darat. Untuk memberikan pelayanan ke daerah pedalaman para penyuluh Katolik biasa menggunakan transportasi sungai seperti perahu. Akan tetapi kendalanya di musim kemarau sungai pedalaman Kalimantan mengalami kekeringan dan tidakbisa dilaluiperahu. Sejak pembukaan lahan hutan untuk perkebunan sawit, sungai-sungai di pedalaman Kalimantan ikut terkena dampaknya. Permukaan air sungai menyurut secara drastis dan pemandangan sungai dipenuhi batu-batu kali yang bisa mengandaskan perahu. Juru mudi perahu tidak bisa mengangkut 
masyarakat yang hendak bebergian ke kota kecamatan maupun yang ingin pulang ke perkampungan. Kondisi ini turut memberi dampak terhadap pelayanan agama yang dilakukan penyuluh fungsional Katolik di Entikong dan Sekayam. Walaupun kondisinya demikian, tetapi pelayanan agama Katolik di perbatasan cukup terbantu oleh rohaniwan Katolik dari Paroki Serian, Bunan, dan Keuskupan Kuching Malaysia. Hal ini disebabkan pengaruh kekerabatan antara Dayak Kalimantan dengan Iban (Dayak) Serawak yang umumnya menjadi penganut Katolik. Ada keluarga yang terpisah oleh perbatasan negara tetapi mereka adalah satu keluarga, yang satu di Entikong dan yang lainnya di SerianBunan. Keluarga dari negara tetangga ini ada yang menjadi pastor dan biasa saling kunjung khususnya pada saat perayaan Natal dan Paskah.

Selain masalah kekurangan SDM penyuluh Katolik, kondisi umat Katolik di Entikong dan Sekayam sebagai obyek Bimbingan dan Penyuluhan Agama (BPA) juga masih kuat mempertahankan adat-istiadat leluhur mereka. Realitas ini dikeluhkan pula oleh penyuluh fungsional dari agama lain, karena pada dasarnya hingga sekarang masyarakat pedalaman masih menempatkan kepercayaan adat sama-sama tinggi dengan kepercayaan agama. Hal ini seperti tersirat dari kebiasaan masyarakat meminum arak dan tuak serta bermain judi pada hari kematian salah satu anggota keluarga mereka. Selain itu dalam melangsungkan perkawinan mereka masih melakukannya di hadapan pemuka adat yang beragama Katholik daripada di hadapan pastor, dan lain-lain. Termasuk penguburan jenazah penganut Katholik di pedalaman dengan mengenakan kain kafan dan tidak menggunakan prosesi yang lazim dilakukan umat Katolik.

Fenomena lain yang patut dicermati dalam ritual adat masyarakat Dayak ialah pembacaan mantera-mantera dengan permulaan membaca "Bismillah" dan ditutup dengan bacaan "Al-Hamdulillah". Bahkan ada kebiasaan orang-orang Dayak, baik di Kalimantan maupun di Serian pada khususnya, mereka biasa melafalkan Tuhan Allah dengan bacaan "Alloh". Pada tahun 2013 persoalan ini sempat menjadi perhatian serius pemerintah Serawak karena dianggap mengkaburkan antara keyakinan Islam dengan Katolik.

Masalah lain yang dihadapi penyuluh Katolik ialah biaya operasional BPA. Pada tahun 2013 penyuluh Katolik hanya mendapat honor Rp. 150.000,-l bulan yang pencairannya harus dilakukan melalui Kantor Cabang BRI Sekayam. Padahal jarak tempuh dari domisili penyuluh ke Kantor BRI lebih dari 25 km dan harus menggunakan transportasi air yang biayanya bisa mencapai Rp. 800.000,- Pada tahun 2014 ini honor penyuluh Katolik dinaikkan menjadi Rp. 300.000,-bulan disamakan dengan honor penyuluh agama lainnya di Kabupaten Sanggau. Kenaikan jumlah honorarium penyuluh fungsional Katholik ini, walaupun masih jauh dari keinginan, diharapkan dapat menunjang kinerja para pelayan Tuhan di daerah perbatasan. (Wawancara dengan Daniel, Penyelenggara Katolik Kantor Kementerian Agama Kabupaten Sanggau, 23 Maret 2014).

6. Bimbingan dan Penyuluhan Agama Kristen

Penganut agama Kristen diEntikong dan Sekayam totalnya berjumlah 6.371 jiwa. Sarana peribadatan umat Krisitiani berupa gereja jumlah keseluruhannya 70 bangunan. Status bangunan gereja dapat diklasifikasikan menjadi: 1). Permanen sebanyak 18 bangunan; 2). Semi permanen sebanyak 5 bangunan; dan 3). Darurat terdapat 2 bangunan. Secara umum, gereja di Entikong dan Sekayam 
tergabung ke dalam 3 denominasi gereja, masing-masing; PGI, Pantekosta, dan Gereja Protestan Indonesia Barat (BPIB). Di samping itu terdapat juga organisasi Jaringan Persekutuan Hamba Tuhan (JPHT) dan para misionaris dari luar daerah maupun dari luar negeri, tetapi belum terpetakan sampai sekarang. Di setiap gereja terdapat SDM Pelayan Umat yang terdiri atas: 1). Pendeta 29 orang; 2). Majelis/penatua 86 orang; 3). Diaken/ Syamas 11 orang; 4). Guru Injil 36 orang; 5). Guru Sekolah Minggu 45 orang; dan 6). Penginjil 17 orang.

Para penginjil yang berjumlah 17 orang ini juga akrab dipanggil "Para Hamba Tuhan". Sekarang ini mereka sudah tergabung dalam organisasi JPHT. Merekainijuga yang didefinitifkan sebagai penyuluh agama Kristen honorer. Hanya saja jumlah penyuluh honorer Kristen pertahunnya tidak tetap menurut jumlah penerima honor dari Kemenag Kabupaten Sanggau. Tahun 2013 penyuluh honorer Kristen se Kabupaten Sanggau sebanyak 20 orang, tapi tahun ini hanya 13 orang; 2 diantaranya melayani umat Kristiani di Entikong dan Sekayam. Perubahan jumlah penerima honorarium penyuluh Kristen di setiap tahunnya ini seringkali mengundang persepsi bahwa pemerintah kurang serius memperhatikan penyuluh agama Kristen. Seolah-olah tidak ada ketentuan yang jelas mengenai masa tugas penyuluh, dan setiap saat daftar penyuluh honorer Kristen bisa digontaganti.

Umumnya para Hamba Tuhan yang didefinitifkan sebagai penyuluh fungsional sudah mengenyam pendidikan Strata Satu. Mereka merupakan lulusan Sekolah Tinggi Teologi Bronio yang terletak di wilayah Sekayam. Perguruan Tinggi para Penginjil ini di bawah binaan langsung Dirjen Bimas Kristen Kementerian Agama RI. Keberadaan perguruan tinggi Kristen ini cukup efektif menyiapkan SDM BPA Kristen di Kabupaten Sanggau secara umum. Pada tahun lalu setiap SDM BPA Kristen hanya mendapatkan tunjangan Rp. 200.000,-/bulan, dan tahun 2014 dibayar Rp. 300.000,-/bulan. Honorarium ini dianggap kurang layak terutama bagi penyuluh Kristen yang ditugaskan di Jalur Sekayam-Noyan. Jalur ini masih sangat terbatas infrastrukturnya dibandingkan Jalur Sutera Entikong-Sekayam.

Menurut salah seorang pendeta, Suyono, para Hamba Tuhan yang ditugaskan di Jalur Sekayam masih kekurangan biaya operasional BPA, seperti untuk pembelian alat musik rohani, buku rohani, dan sebagainya. Selama ini biaya operasinal kegiatan BPA banyak terbantu dari jemaat gereja. Pada saat mereka menjalankan tugas di daerah pedalaman, mereka mendapat tumpangan perahu dari jemaat secara gratis. Tugas penyuluh agama Kristen adalah membantu pelayanan gereja yang dilakukan oleh para pendeta di tingkat Sinode maupun Klasis. Sebaran umat Kristiani yang tidak merata di setiap desa dan jarak tempuh yang sangat jauh menyebabkan pelayanan kepada umat Kristiani kurang maksimal. Contohnya sering terjadi acara perkawinan maupun kematian tidak dipimpin oleh pendeta, tetapi dilakukan oleh sesepuh adat yang bukan sebagai pimpinan agama.

Secara umum problem yang dihadapi penyuluh agama Kristen sama dengan problem penyuluh agama lainnya di kawasan perbatasan. Selain masalah SDM dan infrastruktur pelayanan agama juga ada masalah tugas pokok penyuluh agama fungsional. Hampir semua penyuluh agama fungsional sebatas bertugas membantu pemimpin agama daripada merencanakan, mengorganisasikan, melaksanakan, meneliti, menilai dan mengevaluasi kegiatan BPA.

Atas dasar itulah, umat Kristiani mengharapkan agar jumlah penyuluh 
fungsional agama Kristen diperbanyak jumlahnya. Hanya saja kinerja penyuluh agama Kristen fungsional tidak dipersoalkan karena otoritas kependetaan dalam tradisi gereja Kristen. Mereka juga mengharapkan agar infrastruktur gereja yang meliputi bangunan peribadatan, perpustakaan, dan alat musik rohani dicukupi oleh pemerintah. (Wawancara dengan Supriyadi, Penyelenggara Kristen Kantor Kementerian Agama Kabupaten Sanggau, 23 Maret 2014).

\section{Simpulan}

Berdasarkan analisis data pelayanan agama di daerah perbatasan Entikong Sekayam dapat disimpulkan: Pertama, pelayanan agama di daerah perbatasan masih jauh dari harapan dan tidak mencerminkan prinsip pelayanan yang memuaskan masyarakat sebagaimana ditetapkan dalam Keputusan Men. PAN No. 63/KEP/M.PAN/7/2003. Hal ini disebabkan oleh banyak faktor, terutama: (a). SDM Pemberi Pelayanan Publik baik di KUA maupun Penyuluh Agama Fungsional masih sangat minim, kurang berkompeten, dan kurang terkoordinasi. Selain itu mereka tidak memahami tugas dan fungsi pelayanan KUA dan penyuluhan agama, seperti KUA hanya sebagai balai nikah dan penyuluh agama fungsional menjadi subordinat pemimpin agama non-formal; (b). Lokasi geografis perbatasan yang secara umum masih minim infrastrukturnya dan jaraknya sangat jauh dari pusat kota kecamatan sehingga masyarakat di daerah terpencil tidak terlayani secara maksimal; (c). Penggunaan teknologi informasi dan komunikasi untuk bimbingan dan penyuluhan agama tidak diterapkan oleh penyuluh, khususnya penyuluh agama Islam. Padahal di Entikong terdapat stasiun RRI; (d). Biaya operasional pelayanan umum di bidang agama masih sangat minimal dan tidak sebanding dengan sebaran wilayah yang luas dan berada di pedalaman; (e). Masa tugas pemberi pelayanan public dan pe-roolingannya tidak jelas dan kurang terbuka. Walaupun demikian keterbatasan pelayanan agama di perbatasan tidak mengurangi rasa nasionalisme penduduk perbatasan. Keberadaan barang-barang impor seperti sembako dan lain-lain dari negeri jiran justru membawa berkah bagi mereka tanpa terpengaruh perekonomian nasional.

Kedua, Kementerian Agama, baik pusat, provinsi, maupun kabupaten belum membuat kebijakan maupun program khusus daerah perbatasan termasuk yang berkaitan dengan pelayanan keagamaan. Baik di Entikong maupun di Sekayam, selain madrasah baru ada bangunan KUA yang dibiayai Kementerian Agama. Dengan catatan infrastruktur pelayanan agama di tergolong tertinggal. Indikatornya antara lain: (a). Bangunan KUA Kecamatan sudah berdiri permanen tetapi dari segi sarana-prasarana dan fasilitasnya masih banyak terdapat kekurangan. KUA tidak mempunyai papan struktur, papan prosedur pelayanan, papan pengumuman, papan data statistic, dan lain-lain. Selain itu bangunan KUA tidak dikelilingi pagar dan halamannya dipenuhi rumputliaryang kurang terawat; (b). Sarana peribadatan, baik masjid maupun gereja, dan fasilitas pendidikan agama seperti TPA, Pesantren, Sekolah Minggu, perpustakaan mesjid serta gereja dan lainnya lebih banyak bersifat semi permanen dan darurat dan berdiri di atas tanah yang belum bersertifikat hak milik maupun wakaf; (c). Sarana kendaraan operasional KUA maupun penyuluh agama tidak diadakan untuk menunjang mobilitas petugas lapangan di wilayah tugas yang sangat luas dan sulit dijangkau dengan menggunakan transportasi massal; (d). Pendistribusian kitab suci, buku nikah, dan dokumen lain seperti NR tidak berdasarkan analisis kebutuhan. Misalnya kitab suci sangat 
kekurangan tetapi buku nikah dan dokumen NR kebanyakan. Pernah terjadi jual beli buku nikah di Entikong karena buku nikah yang seharusnya ditarik dari KUA masih dibiarkan beredar di tangan Penghulu dan Pembantu Penghulu (P3N).

Ketiga, masyarakat di perbatasan Entikong sangat memerlukan pelayanan keagamaan. Kebutuhan itu, antara lain: (a). Umat Islam menginginkan agar KUA dioptimalkan fungsinya dalam melayani urusan nikah dan rujuk, keluarga sakinah, Kemasjidan, ZISWA, dan informasi pendidikan agama, haji dan umrah. Mereka mengharapkan agar di KUA terdapat Kepala Kantor, Penyuluh Agama Islam dan beberapa staf yang dibutuhkan; tidak seperti sekarang di KUA hanya ada satu orang staf. Selain KUA, umat Islam di perbatasan mengharapkan dibangunkannya pendidikan keagamaan seperti pesantren untuk mengkader calon ulama dan muballigh; (b). Umat Katolik dan Kristen menginginkan agar jumlah penyuluh agamanya diperbanyak dengan rasio 1 penyuluh untuk 1.000 penduduk. Hal ini karena jumlah pemeluk Katolik dan Kristen merupakan mayoritas yang tersebar di seluruh penjuru dan pelosok Kabupaten Sanggau. Selain itu mereka juga mengharapkan adanya bantuan infrastruktur, terutama berupa renovasi gereja, pensertifikasian tanah gereja, pengadaan perpustakaan dan alat musik rohani.

\section{Ucapan Terima Kasih}

Di akhir tulisan ini, penulis sangat berterima kasih kepada Kepala Puslitbang Bimas Agama dan Layanan Keagamaan serta Kepala Badan Litbang dan Diklat Kementerian Agama RI yang telah memberikan kesempatan kepada penulis untuk melakukan penelitian tentang isu yang diangkat dalam tulisan ini, juga beberapa pihak dan informan yang terlibat dalam penggalian data dan informasi di dalamnya. Tidak ketinggalan, terima kasih juga penulis tujukan kepada Mitra Bestari Jurnal Harmoni yang telah memberikan catatan dan saran untuk perbaikan tulisan ini.

\section{Daftar Pustaka}

Ahimsa-Putra, Heddy Shri. Pola Komunikasi Budaya Antara Etnis, makalah yang disampaikan dalam Pembinaan Teknis Sosial Budaya, Direktorat Sejarah dan Nilai Tradisional, Depdikbud, Bogor, 1999.

Appadurai, Arjun. "Introduction: Commodities and the Politics of Value" dalam Arjun Appadurai (ed.), The Social Life Things. Cambridge: Cambridge University Press, 1991.

“The Production of Locality", dalam R. Fardon (ed.), Counterworks : Managing the Diversity of Knowledge, Routledge, London, 1995.

Baker, Chris. Cultural Studies: Theory and Practice. London: sage Publication, 2000.

Baudrillard, Jean. Simulation. New York: Semiotext(e), 1983.

Berger, Peter dan Thomas Luckmann, The Social Construction of Reality. Penguin Books, New York, 1979. 
Beyer, Peter. "Privatization dan Public Inflence of Religion in Global Society" dalam Mike Featherstone (ed.), Global Culture: Nationalism, Globalization and Modernity. London: sage Publication, 1991.

Cheater, Angela. The Anthropology of Power, Routledge, London, 1999.

Ewen, Stuart. "Marketing Dreams: The Political Element of Style", dalam Alan Tomlison (ed.,), Consumption Identity and Style: Marketing Meanings and the Packaging of Pleasure. London NewYork: Routledge, 1990.

Featherstone, Mike. Global Culture: Nationalism, Globalization, and Modernity. London: Sage Publications, 1991.

Geertz, Clifford. Available Light : Anthropological Reflections on Phylosophical Topics. Princeton University Press, Princeton, New Jersey, 2000.

Green, J.W. Cultural Awarness in the Human Service, Allyn and Bacon, Boston, 1995.

Kotler, Philip. Marketing Management, 11 ${ }^{\text {th }}$ Edition. Prentice Hall Int'l, New Jersey, 2013.

Lyotard, Jean-François. Posmodernisme: Krisis dan Masa Depan Pengetahuan, Yogyakarta: Teraju, 2004.

Moeldoko. Kebijakan dan Scenario Planing Pengelolaan Kawasan Perbatasan. Disertasi Program Pascasarjana UI, 2014.

Moenir. Manajemen Pelayanan Publik. Jakarta: Bina Aksara, 2006. 